\title{
Batas Waktu Pelaksanaan Pidana Mati dalam Perspektif Kepastian Hukum dan Keadilan di Indonesia
}

\section{Leo Arwansyah, Andi Najemi, Aga Anum Prayudi}

Fakultas Hukum, Universitas Jambi

Author's Email Correspondence: l.arwansyah210@gmail.com

\begin{abstract}
ABSTRAK
Tujuan artikel ini adalah untuk mengetahui bagaimana aspek kepastian hukum dan keadilan dalam pelaksanaan pidana mati di Indonesia serta bagaimana konsep batas waktu pelaksanaan pidana mati yang berkepastian hukum dan berkeadilan. Dengan menggunakan metode yuridis normatif, artikel ini menunjukkan aspek kepastian dan keadilan mengenai pengaturan batas waktu pelaksanaan pidana mati masih belum terdapat pengaturannya di dalam hukum positif, praktik pidana mati kerap menimbulkan persoalan terkait batas waktu pelaksanaan eksekusi, aspek kepastian hukum dan keadilan bagi terpidana mati belum terjamin, sehingga perlu pembaharuan terhadap peraturan perundangundangan terkait pelaksanaan pidana mati baik dalam hukum pidana materiil, hukum pidana formal, maupun hukum pelaksanaan pidana.
\end{abstract}

Kata Kunci: Batas waktu; kepastian hukum; keadilan; pidana mati.

\section{ARTICLE HISTORY}

Submission: 2020-11-19

Accepted: 2020-12-02

Publish: 2020-12-02

Keywords: Limitation; legal certainty; justice; death sentence.

\begin{abstract}
The purpose of this article is to find out how the aspects of legal certainty and justice in the implementation of the death penalty in Indonesia and how the concept of the deadline for the execution of capital punishment that is legal and just. By using the normative juridical method, this article shows that the aspects of certainty and justice regarding the time limit for the implementation of the death penalty are still not regulated in positive law, the practice of capital punishment often raises problems related to the time limit for execution, aspects of legal certainty and justice for death convicts have not. guaranteed, so that it is necessary to renew the laws and regulations related to the implementation of the death penalty both in material criminal law, formal criminal law, and criminal law enforcement.
\end{abstract}

\section{A. PENDAHULUAN}

Penerapan pidana mati di Indonesia sampai saat ini masih tetap dipertahankan melalui Putusan Mahkamah Konstitusi Nomor:2-3/PUU-V/2007 mengenai permohonan uji materiil terhadap sanksi pidana mati yang terdapat dalam Undang-Undang Nomor 22 Tahun 1997 tentang Narkotika. Konklusi dalam Putusan Mahkamah Konstitusi tersebut menyatakan bahwa ketentuan dalam Undang-Undang Nomor 22 Tahun 1997 tentang Narkotika tentang ancaman pidana mati tidak bertentangan dengan Pasal 28A dan 
Pasal 28I Ayat (1) Undang-Undang Dasar Negara Republik Indonesia Tahun 1945 yang menjamin hak untuk hidup. Sejalan dengan hal tersebut dalam Undang-Undang Hak Asasi Manusia tepatnya pada Penjelasan Pasal 9 Ayat (1) menyatakan bahwa: "Penjatuhan pidana mati dalam keadaan tertentu tidak melanggar hak untuk hidup". Pelaksanaan pidana mati diatur melalui Undang-Undang Nomor 2/Penpres/1964 tentang Tata Cara Pelaksanaan Pidana Mati yang dijatuhkan oleh Pengadilan di Lingkungan Peradilan Umum dan Militer, namun terdapat kekosongan norma yang mengatur kapan batas akhir pelaksanaan eksekusi pidana mati demikian pula dalam undang-undang terkait.

Berdasarkan data Direktorat Jenderal Pemasyarakatan Kementerian Hukum dan HAM yang telah diolah oleh tim ICJR, data rekapitulasi terpidana mati yang belum dieksekusi per 9 Oktober 2019 yang memuat 274 orang dengan persebaran usia antara 20-30 tahun sebanyak 50 orang, usia 31-40 tahun sebanyak 73 orang, usia 41-50 tahun sebanyak 88 orang, dan usia $>50$ tahun sebanyak 63 orang. ${ }^{1}$ Terpidana mati yang mengajukan upaya hukum atau permohonan grasi, maka proses ekseksusi tidak dapat dilaksanakan sampai adanya Keputusan Presiden tentang penolakan grasi yang kemudian telah diterima oleh terpidana mati².

"Pelaksanaan eksekusi mati harus memperhatikan kepentingan hak-hak terpidana mati. Secara yuridis memang dibenarkan untuk dilakukannya penundaan eksekusi, pertama, adanya permintaan penundaan dari terpidana, kedua, terpidana dalam keadaan hamil, ketiga, terpidana mengajukan grasi, keempat,terpidana mengajukan upaya hukum luar biasa berupa kasasi demi kepentingan hukum dan peninjauan kembali kepada Presiden."

Terpidana mati yang menjalani masa tunggu, berada dalam ketidakpastian dan hal tersebut merupakan bentuk pelanggaran Hak Asasi Manusia lanjutan bagi terpidana mati. ${ }^{4}$ Antara lain, pidana ganda (double punishment) terpidana mati menjalani pembinaan seperti warga binaan tanpa batas waktu yang ditentukan ${ }^{5}$, terpidana mati menghadapi dua jenis pidana pokok yaitu pidana penjara dan pidana mati.

Selain itu masa tunggu yang terlalu lama berimbas pada kesehatan mental terpidana mati yang mengakibatkan tekanan psikis, stress, serta perasaan takut yang berkepanjangan. Sebagai contoh terpidana mati yang mengalami tekanan psikis ada terpidana mati Sugiono alias Sugik. Sugiono alias Sugik merupakan terpidana mati atas tindak pidana pembunuhan satu keluarga yang dilakukannya pada tahun 1995 silam.

1 Adhigama Andre Budiman dan Maidina Rahmawati, Fenomena Deret Tunggu Terpidana Mati di Indonesia (Jakarta selatan: Institute for Criminal Justice Reform, 2020), hlm. 22.

2 Leny Oktavia, "Pelaksanaan Pembinaan Narapidana yang Dijatuhi Pidana Mati (Studi Kasus Lembaga Permasyarakatan Kelas 1 A Raja Basssa Bandar Lampung)" Poenale: Jurnal Bagian Hukum Pidana, (2019), hlm. 3.

3 Roni Efendi, "Konstitusionalitas Masa Tunggu Eksekusi Bagi Terpidana Mati dalam Sistem Pemidanaan", Jurnal Konstitusi, Vol. 16, No. 2 (2019), hlm. 305-306.

4 Erasmus A.T. Napitupulu, Laporan Situasi Kebijakan Hukuman Mati di Indonesia: "Mempermainkan Takdir", (2019), hlm. 23.

5Djernih Sitanggang, Kepastian Hukum Masa Tunggu Eksekusi Pidana Mati Dalam Mewujudkan Rasa Keadilan Menuju Pembaharuan Hukum Pidana (Bandung: Pustaka Reka Cipta, Cet. Pertama, 2018), hlm. 18. 
Saat ini menderita gangguan kejiwaan dan pada akhirnya eksekusi pidana mati terancam tidak dapat terlaksana sampai yang bersangkutan pulih dari keadaannya. ${ }^{6}$ Dampak negatif lainnya ialah adanya peluang untuk kembali melakukan atau mengulang tindak pidana dengan memanfaatkan waktu selama berada di Lembaga Pemasyarakatan, Pengulangan tindak pidana dapat dijadikan modus operandi oleh terpidana guna memperpanjang proses hukum yang akan dijalani oleh terpidana mati. Seperti hal nya yang dilakukan oleh Freddy Budiman, mengendalikan bisnis narkotika. ${ }^{7}$

Penundaan eksekusi pidana mati menunjukan sisi yang berseberangan, disatu sisi penundaan menunjukan sikap kehati-hatian dari penegak hukum karena ketika eksekusi telah dilaksanakan maka tidak dapat diperbaiki lagi, akan tetapi di sisi lain penundaan eksekusi pidana mati akan menimbulkan ketidakjelasan nasib terpidana mati yang ditunda eksekusinya. ${ }^{8}$

Untuk terlepas dari permasalahan pelik seperti yang tersebut maka sudah seharusnya dilakukan perubahan terhadap pengaturan batas waktu pelaksanaan pidana mati melaui pembangunan hukum. Menurut Shidarta untuk mengarahkan ke pembangunan hukum, pembangunan mensyaratkan adanya iklim politik yang sehat, yang mampu memberikan ruang diskursus publik yang leluasa dan cukup bernas untuk ikut mengoreksi kualitas hukum (undang-undang) yang dibentuk penguasa. ${ }^{9}$

"Pembangunan hukum merupakan salah satu elemen yang sangat mendasar (fundamental) dalam pembaharuan hukum nasional yang sedang digagas oleh pemerintah. Pembaharuan hukum pidana meliputi hukum pidana materil (substantive), hukum pidana formil (hukum acara pidana) dan hukum pelaksanaan pidana (strafvollstreckuengsgesetz)."10

Terdapat skema dalam kebijakan pidana mati dalam Rancangan KUHP, menjadikan pidana mati sebagai pidana yang bersifat khusus dan hanya diancamkan secara alternatif. ${ }^{11}$ Pemerintah memberikan upaya komutasi untuk hukuman pidana mati, hakim dapat menjatuhkan pidana mati dengan masa percobaan selama 10 (sepuluh) tahun dan pidana mati dapat diubah menjadi pidana penjara seumur hidup. ${ }^{12}$ Namun draft RKUHP versi terakhir yakni September 2019, komutasi hukuman mati tidak dapat secara otomatis diterapkan dikarenakan bergantung pada pernyataan hakim yang menghendaki adanya masa percobaan terhadap terpidana mati yang

6 Hilda Meilisa, "Eksekusi Mati Sugik, Pembunuh Satu Keluarga Mungkin Dibatalkan, Ini Sebabnya", Detik News, Berita Jawa Timur, 31/12/2019, diakses pada tanggal 17 Februari 2020.

7 Dhani Irawan, "Cerita Freddy Budiman Atur Bisnis Narkoba dan Nyabu Bareng Model Dilapas", Detik News, Berita, 29/7/2016, diakses pada tanggal 31 Oktober 2019.

8 Marselinus Yohanes Rian Asmaran, "Pelaksanaan Aturan Limitasi Waktu Eksekusi Terpidana Mati", Jurnal Universitas Atma Jaya Yogyakarta, (2017), hlm. 7.

9 M. Zulfa Aulia, "Hukum Pembangunan dari Mochtar Kusumaatmadja: Mengarahkan Pembangunan atau Mengabdi pada Pembangunan", Undang Jurnal Hukum, Vol.1 No.2 (2018), hlm. 386.

10 Dey Ravena dan Kristian, Kebijakan Kriminal (Criminal Policy) (Jakarta: Kencana, Cet. Pertama, 2017), hlm. 266.

11 Pasal 67 RKUHP Tahun 2019.

12 Pasal 100 RKUHP Tahun 2019. 
bersangkutan. ${ }^{13}$ Sehingga skema ini di masa yang akan datang sulit untuk dipertahankan dan diterapkan dalam upaya memutus angka deret tunggu terpidana mati.

\section{B. METODE PENELITIAN}

Artikel ini menggunakan metode yuridis normatif, dimana berangkat dari adanya isu hukum yang dilakukan untuk menghasilkan argumentasi, teori atau konsep baru sebagai preskripsi dalam mengahadapi masalah yang dihadapi dan diperoleh dari studi kepustakaan, dengan menganalisis suatu permasalahan hukum melalui peraturan perundang-undangan, literatur-literatur dan bahan-bahan referensi lainnya. Mengkaji aturan hukum tentang pelaksanaan pidana mati yang dimuat dalam KUHP dan UndangUndang Nomor 2/PN PS/1964 tentang Tata Cara Pelaksanaan Pidana Mati yang dijatuhkan oleh Pengadilan di Lingkungan Peradilan Umum dan Militer.

\section{PEMBAHASAN}

\section{Aspek Kepastian Hukum dan Keadilan dalam Pelaksanaan Pidana Mati di Indonesia}

Menurut Jan Remmelink, hukum pidana akan bersinggungan dengan nilai-nilai kemanusiaan. Di satu sisi bertujuan untuk memberikan perlindungan kepada masyarakat, sedangkan di sisi lainnya penegakan hukum pidana menimbulkan penderitaan bagi individu yang melanggarnya. ${ }^{14}$ Peranan aparat penegak hukum dalam proses penegakan hukum sangat menentukan arah dan tujuan serta hasil yang akan dicapai dalam penegakan hukum. ${ }^{15}$

Pelaksanaan eksekusi pidana mati dijalankan menurut Undang-Undang Nomor 2/Pnps/1964 yaitu Penpres Nomor 2 Tahun 1964 yang telah ditetapkan menjadi Undang-Undang Nomor 5 Tahun 1969 tentang Tata Cara Pelaksanaan Pidana Mati yang Dijatuhkan oleh Pengadilan di Lingkungan Peradilan Umum dan Militer. Di dalam peraturan pelaksana tidak pengaturan mengenai kapan batas waktu pelaksanaan eksekusi terpidana mati, baik yang tengah mengajukan upaya hukum maupun yang tidak mengajukan upaya hukum.

Pasal 3 Undang-Undang Nomor 22 Tahun 2002 tentang Grasi. Dalam upaya pemenuhan hak permohonan grasi justru makin memperpanjang deret tunggu, karena tidak diketahui berapa lama waktu yang diperlukan untuk dikeluarkannya Keputusan Presiden yang berisi diterima atau ditolaknya permohonan grasi yang diajukan terpidana mati. Terpidanamati yang mengajukan upaya hukum atau permohonan grasi, proses eksekusinya tidak dapat dilaksanakan sebelum adanya Keputusan Presiden tentang penolakan permohonan grasi yang kemudian telah diterima oleh terpidana mati. 16

13 Erasmus A.T. Napitupulu, Laporan Situasi, hlm. 24.

14 Djernih Sitanggang, Kepastian Hukum, hlm. 214.

15 Monika Dwi Putri Nababan dan Kabib Nawawi, "Pelaksanaan Hak Tahanan (Tantangan dan Permasalahan)", PAMPAS: Journal of Criminal Law, Vol. 1, No. 1 (2020), hlm. 82.

16 Leny Oktavia, "Pelaksanaan Pmbinaan”, hlm. 3. 
Berikut rekapitulasi data seacara keseluruhan jumlah terpidana mati yang tengah menjalani masa tunggu eksekusi ditunjukkan tabel diberikut ini: ${ }^{17}$

Tabel 1.1

Data Terpidana Mati Ditjen PAS 2020 Per Bulan Oktober 2020

\begin{tabular}{ccc}
\hline No & Persebaran Kasus & Terpidana Mati \\
\hline $\mathbf{1 .}$ & Narkotika & 214 orang \\
\hline $\mathbf{2 .}$ & Pembunuhan & 119 orang \\
\hline $\mathbf{3 .}$ & Perampokan & 8 orang \\
\hline $\mathbf{4 .}$ & Psikotropika & 8 orang \\
\hline $\mathbf{5 .}$ & Terorisme & 4 orang \\
\hline $\mathbf{6 .}$ & Penculikan dan Penganiayaan & 1 orang \\
\hline & Jumlah & $\mathbf{3 5 5}$ orang
\end{tabular}

Fenomena terpidana mati yang berada dalam deret tunggu eksekusi tengah menghadapi sebuah ketidakpastian dan hal tersebut merupakan bentuk pelanggaran Hak Asasi Manusia bagi terpidana mati. ${ }^{18}$ Terpidana mati yang belum dieksekusi ditempatkan di LAPAS akan menunggu sampai waktu yang belum ditentukan, dengan demikian berarti LAPAS telah melampaui fungsi utama yaitu melaksanakan pembinaan terhadap narapidana.

Jika dilihat dari permasalahan tersebut masa tunggu yang terlalu lama bertentangan dengan Pasal 28D Undang-Undang Dasar Republik Indonesia 1945 jo Pasal 3 Undang-Undang No. 39 tahun 1999 tentang Hak Asasi Manusia, setiap warga negara berhak mendapatkan kepastian hukum. "Konsep kepastian hukum mengandung dua prinsip mendasar, pertama, adanya peraturan perundang-undangan yang dapat dijadikan sebagai dasar atau acuan dalam bertindak.Kedua, adanya penerapan atau penegakan hukum yang konsisten dalam hal pelanggaran hukum."19

Berdasarkan Pasal 1 butir 3 Undang-Undang Nomor 12 Tahun 1995 tentang Pemasyarakatan menjelaskan bahwa Lembaga Pemasyarakatan adalah tempat untuk melaksanakan pembinaan Narapidana dan Anak Didik Pemasyarakatan. Sementara terpidana adalah seseorang yang dipidana berdasarkan putusan pengadilan yang telah memperoleh kekuatan hukum tetap. ${ }^{20}$ Lembaga Pemasyarakatan ikut dihuni oleh terpidana mati, baik yang sedang mengajukan upaya hukum maupun yang telah ditolak grasinya oleh Presiden.

Sejatinya tujuan dan fungsi Sistem Pemasyarakatan adalah menekankan pada perbaikan diri warga binaan agar dapat diterima kembali sebagai anggota masyarakat

17 Adhigama Andre Budiman, Laporan Situasi Kebijakan Hukuman Mati di Indonesia 2020: Mencabut Nyawa di Masa Pandemi (Jakarta Selatan: Institute for Justice and Criminal Reform, 2020), hlm. 22.

18 Erasmus A.T. Napitupulu, Laporan Situasi, hlm. 23.

19 Usman dan Andi Najemi, "Mediasi Penal di Indonesia: Keadilan, Kemanfaatan, dan Kepastian Hukumnya", Undang: Jurnal Hukum, Vol.1 No.1 ( 02018), hlm. 80.

20 Pasal 1 butir 6 Undang-Undang Nomor 12 Tahun 1995 tentang Pemasyarakatan. 
yang bebas, baik, dan bertanggungjawab, maka dengan aturan yang berlaku saat ini Sistem Pemasyarakatan tidak berlaku bagi terpidana mati.

Pasal 28D Ayat (1) UUD NKRI 1945, yang mengamanatkan: "Setiap orang berhak atas pengakuan, jaminan, perlindungan, dan kepastian hukum yang adil serta perlakuan yang sama dihadapan hukum."Terpidana mati berhak untuk mendapatkan keadilan dan kepastian hukum, tindakan pemerintah yang menggantungkan nasib terpidana mati dalam masa tunggu eksekusinya, maka dapat dikategorikan sebagai bentuk pelanggaran terhadap Hak Asasi Manusia. ${ }^{21}$

Kejaksaan memprioritaskan eksekusi terpidana mati pada kasus tertentu merupakan salah satu bentuk pelanggaran terhadap ketentuan konstitusional. Pasal 28I Ayat (2) UUD NKRI 1945, mengamanatkan; "Setiap orang berhak bebas dari perlakuan yang bersifat diskriminatif atas dasar apapun dan berhak mendapatkan perlindungan terhadap perlakuan yang bersifat diskriminatif." Maka sudah jelas diskresi yang dilakukan oleh Kejaksaan tidak dibenarkan secara konstitusional.

Periode saat ini terpidana mati yang telah dieksekusi periode 2014-2016 menurut data dari Kejaksaan Agung Republik Indonesia yang ditunjukan pada tabel berikut: 22

Tabel 1.2

Eksekusi Pidana Mati Tahun 2014-2016

\begin{tabular}{|c|c|c|c|c|c|}
\hline \multirow[t]{3}{*}{ No } & \multirow{3}{*}{$\begin{array}{c}\text { TERPIDANA } \\
\text { MATI }\end{array}$} & \multirow[t]{3}{*}{2014} & \multicolumn{2}{|c|}{2015} & \multirow[t]{3}{*}{2016} \\
\hline & & & 18 & 29 APRIL & \\
\hline & & & \multicolumn{2}{|l|}{ JANUARI } & \\
\hline 1. & Pembunuhan & - & - & - & - \\
\hline 2. & Terorisme & - & - & - & - \\
\hline \multirow[t]{4}{*}{3.} & Narkotika & - & 6 & 8 & 4 \\
\hline & & & (5 WNA \& & (7 WNA \& & (3 WNA \& \\
\hline & & & $1 \mathrm{WNI})$ & $1 \mathrm{WNI}$ & $1 \mathrm{WNI}$ \\
\hline & JUMLAH & & 6 & 8 & 4 \\
\hline
\end{tabular}

Berdasarkan tabel di atas maka dapat disimpulkan bahwa tidak adanya pengaturan yang diberlakukan secara tegas dan pasti mengenai batas waktu pelaksanaan ekseskusi pidana mati sehingga aspek kepastian hukum dan keadilan dapat dikatakan belum terpenuhi, peristiwa ini menyebabkan terjadinya penumpukan jumlah terpidana mati yang belum dieksekusi oleh Kejaksaan. Presiden melalui Kejaksaan melaksanakan diskresi eksekusi terhadap terpidana dengan

21 Djernih Sitanggang, Kepastian Hukum, hlm. 280.

22 Djernih Sitanggang, Kepastian Hukum, hlm. 128. 
memprioritaskan terpidana mati untuk tindak pidana narkotika sebagai upaya pemberantasan narkotika di indonesia.

Diskresi yang dilakukan berdampak pada masa tunggu atau waktu yang dijalani oleh terpidana mati, diskresi tersebut mengakibatkan adanya disparitas antara terpidana mati yang satu dengan terpidana mati lainnya. Banyaknya terpidana mati yang belum dieksekusi merupakan pekerjaan rumah yang harus segera dikerjakan oleh Kejaksaan dan tentu saja memerlukan bantuan pemerintah selaku pembentuk kebijakan.

Pasal 28G Ayat (2) UUD NKRI 1945, menegaskan bahwa: "Setiap orang berhak untuk bebas dari penyiksaan atau perlakuan yang merendahkan derajat martabat manusia dan berhak memperoleh suaka politik dari negara lain."Dengan adanya ketidakpastian hukum maka akan berimplikasi pula pada kesehatan mental terpidana mati, menempatkannya dalam tekanan psikis yang berkepanjangan merupakan bentuk siksaan yang diterima oleh terpidana mati.

Data Terpidana Mati Ditjen PAS 2020 tidak mencantumkan tanggal putusan terakhir terpidana mati, ICJR mengolah data per tanggal 28 September 2020 hingga 1 Oktober 2020 dengan jumlah total terpidana mati yang dapat dihitung lama masa tunggu eksekusinya adalah sebanyak 350 orang. Berikut masa tunggu yang dijalani terpidana mati: 23

Tabel 1.3

Rentang Masa Tunggu Terpidana Mati

\begin{tabular}{ccc}
\hline $\mathbf{N}$ & Masa Tunggu & Jumlah Terpidana \\
$\mathbf{0}$ & & \\
\hline $\mathbf{1}$ & $<5$ Tahun (sejak 2016) & 202 orang \\
\hline $\mathbf{2}$ & $5-10$ Tahun (sejak 2011) & 85 orang \\
\hline $\mathbf{3}$ & $10-15$ Tahun (sejak 2006) & 37 orang \\
\hline $\mathbf{4}$ & $15-20$ Tahun (sejak 2001) & 23 orang \\
\hline $\mathbf{5}$ & $>$ 20 Tahun (sejak 1979) & 3 orang \\
\hline & Jumlah & $\mathbf{3 5 0}$ orang \\
\hline
\end{tabular}

Dari data rentang masa tunggu terdapat 63 orang terpidana mati yang telah berada didalam tahanan selama lebih dari 10 tahun. Bahkan terdapat 3 orang terpidana mati yang memiliki masa tunggu paling panjang, yakni lebih dari 20 tahun dengan berada dideret tunggu sejak 1983, 1997, dan 1998. ${ }^{24}$ Salah satunya terpidana mati yang bernama Eddy Maulana Sampak bin M. Santaka (Alm), beliau telah melampaui masa hidupnya dengan menanti untuk dieksekusi. ${ }^{25}$

3 Adhigama Andre Budiman, Laporan Situasi, hlm. 26.

Adhigama Andre Budiman, Laporan Situasi, hlm. 26.

25 Erasmus A.T. Napitupulu, Laporan Situasi, hlm. 24. 
Batas waktu pelaksanaan eksekusi pidana mati yang tidak diatur secara tegas dan pasti mengakibatkan masa tunggu yang dijalani oleh terpidana mati kian jauh dari makna kepastian dan keadilan dalam pelaksanaan pidana mati. Tentunya akan membawa dampak negatif bagi terpidana mati. Dampak negatif yang diterima oleh terpidana mati ada beberapa persoalan, yaitu:

1. Hukuman Ganda (Double Punishment)

Terpidana mati harus menjalani 2 (dua) jenis pidana pokok, yaitu: Pertama, pidana penjara untuk waktu yang tidak ditentukan dengan ditempatkan di Lapas sampai pada waktu pelaksanaan eksekusi mati; kedua, pidana mati itu sendiri sesuai dengan putusan pengadilan yang telah berkekuatan hukum tetap. Bambang Waluyo mengemukakan "Seolah-olah disatu pihak terdakwa yang dijatuhi hukuman mati oleh pengadilan, harus menjalani dua jenis hukuman atas satu perbuatan yang sama yaitu hukuman mati dan hukuman penjara." 26

2. Tekanan Psikis

Kondisi mental yang dialami oleh terpidana mati akibat tidak diaturnya batas waktu pelaksanaan eksekusi mati menyebabkan terpidana mati berada pada kondisi gangguan atau tekanan psikis, yakni stress, tekanan kejiwaan, serta rasa takut yang berkepanjangan. Hal tersebut diperparah dengan tidak diberikannya program pembinaan terhadap terpidana mati maka akan berpotensi membahayakan dirinya sendiri serta membahayakan orang lain dalam berinteraksi dengan sesama penghuni di Lapas.

Guru Besar Fakultas Psikologi Universitas Padjajran, Diana Harding menyampaikan bahwa:

"Secara umum setiap orang akan merasa takut dan cemas dalam menghadapi kematian, termasuk terpidana mati. Kondisi ini sangat dipengaruhi oleh faktor internal dan eksternal. Faktor internal berasal dari kepribadian narapidana itu sendiri, jika terpidana mati terus memikirkan dan menghayati mengenai kematiannya maka yang bersangkutan akan terus berada pada posisi ketakutan dan kecemasan. Begitu juga dengan faktor eksternal yang berasal dari dukungan keluarga, jika keluarga tidak memberikan dukungan kepada terpidana mati maka yang bersangkutan akan selalu berada pada kondisi ketakutan dan kecemasan dalam menghadapi kematian."27

Perlakuan yang tidak mewajibkan kepada terpidana mati untuk mengikuti program pembinaan dalam Lapas, maka dapat dikatakan bertentangan dengan Hak Asasi Manusia untuk mendapatkan pelayanan Kesehatan atas kondisi gangguan tekanan psikis yang dialami. Negara dalam hal ini telah lalai dalam memberikan pelayanan kesehatan secara wajib kepada terpidana mati.

3. Pengulangan Tindak Pidana

Pengulangan tindak pidana yang dilakukan oleh terpidana mati selama menunggu di Lapas terjadi karena batas waktu pelaksanaan eksekusi mati terlalu lama. Pengulangan tindak pidana tidak terjadi semata-mata karena minimnya pengawasan terhadap terpidana mati namun juga dapat dikarenakan Sistem Pemasyarakatan tidak memberikan Progam Pembinaan yang wajib terhadap terpidana layaknya warga

26 Bambang Waluyo, Penegakan Hukum di Indonesia (Jakarta: Sinar Grafika, 2016), hlm. 33.

27 Djernih Sitanggang, Kepastian Hukum, hlm. 270. 
binaan lainnya.Hal tersebut terbukti pada terpidana mati perkara narkotika, yakni pada kasus Freddy Budiman. Tepidana mati Freddy Budiman mengendalikan bisnis narkotika saat berada di Lapas Cipinang selama menunggu eksekusi mati. ${ }^{28}$

4. Bertentangan dengan Hak Asasi Manusia

Dampak negatif dari tidak diaturnya batas waktu pelaksanaan eksekusi mati maka bertentangan dengan Hak Asasi Manusia antara lain Pasal 28D Ayat (1), Pasal 28G Ayat (2) UUD NKRI 1945, Pasal 28D Ayat (1), dan Pasal 28I Ayat (2) UUD NKRI 1945.

Pasal 28D Ayat (1) UUD NKRI 1945 yang secara tegas mengamanatkan bahwa: "Setiap orang berhak atas pengakuan, jaminan, perlindungan, dan kepastian hukum yang adil serta perlakuan yang sama di hadapan hukum." Ketentuan Pasal 28D Ayat (1) UUD NKRI 1945 secara substansial menjelaskan bahwa pada dasarnya semua orang berhak mendapatkan rasa kepastian hukum dan keadilan, tidak terkecuali terpidana mati. Maka tindakan pemerintah yang menggantung nasib terpidana mati sudah termasuk kedalam bentuk pelanggaran terhadap Hak Asasi Manusia.

Pasal 28G Ayat (2) UUD NKRI 1945 mengamanatkan bahwa: "Setiap orang berhak untuk bebas dari penyiksaan atau perlakuan yang merendahkan derajat martabat manusia dan berhak memperoleh suaka politik dari negara lain." Substansi pasal di atas menegaskan mengenai larangan terhadap segala bentuk penyiksaan, baik fisik maupun psikis kepada semua orang. Pengaturan mengenai batas waktu pelaksanaan eksekusi pidana mati yang tidak diatur secara tegas, menyebabkan keadaan terpidana mati dibawah tekanan psikis karena memikirkan waktu eksekusinya.Tekanan psikis yang dialami terpidana dapat dikualifikasikan sebagai tindakan penyiksaan khususnya psikis, dan hal tersebut bertentangan dengan Hak Asasi Manusia.

Selanjutnya Pasal 28I Ayat (2) UUD NKRI mengamanatkan bahwa: "Setiap orang berhak bebas dari perlakuan yang bersifat diskriminatif atas dasar apapun dan berhak mendapatkan perlindungan terhadap perlakuan yang bersifat diskriminatif."Sifat diskriminatif disini terlihat dari perbedaan antara terpidana satu dengan yang lain dalam hal menunggu eksekusi, selain itu berkaitan pula dengan perlakuan terhadap terpidana mati pada saat berada di Lapas.

"Eksekusi pidana mati yang dilaksanakan secara cepat tentu akan memberikan landasan kepastian hukum yang berkeadilan dalam prosesnya. Memberikan perlindungan Hak Asasi Manusia bagi terpidana mati, korban, dan masyarakat luas, bahkan juga meningkatkan kewibawaan sebagai negara hukum."29

Pasal 1 Ayat (3) UUD NRI 1945 menyatakan bahwa Indonesia adalah negara hukum, maka sudah seyogyanya sebagai perwujudan dari negara hukum perlu diatur lebih lanjut secara tegas dan pasti mengenai pembaharuan regulasi mengenai batas waktu eksekusi pidana mati. Pembaharuan harus dilaksanakan secara komprehensif dengan tidak berfokus pada pasca penolakan grasi oleh Presiden, melainkan juga

28 Ita Lismawati F. Malau, "Rentetan Kasus Hukum Freddy Budiman si Gembong Narkoba", Viva News, Berita, 30/09/2010, diakses pada tanggal 02 Februari 2020.

29 Bambang Waluyo, Penegakan Hukum, hlm. 35. 
ketentuan-ketentuan yang mengatur mengenai upaya hukum luar biasa peninjauan kembali dan grasi.

Indonesia telah meratifikasi Kovenan Sipol melalui Undang-Undang Nomor 12 Tahun 2005 tentang Pengesahan International Convenant on Civil and Political Rights. Konvenan Sipol mengatur lebih rinci mengenai jaminan fair trial guna melindungi hakhak individu dari kesewang-wenangan. Pasal 6 Ayat (1) ICCPR mengatur mengenai hak untuk hidup dan mengatur mengenai pembatasan pidana mati, dengan menyatakan: ${ }^{30}$

"Every human being has the inherent right to life. This right shall be protected by law. No one shall be arbitrally deprived of his life."

(Setiap manusia berhak atas hak untuk hidup yang melekat pada dirinya. Hak ini wajib dilindungi oleh hukum. Tidak seorang pun dapat dirampas hak hidupnya secara sewenang-wenang).

Sekilas pada ketentuan Pasal 6 Ayat (1) menunjukan bahwa adanya keinginan dari ICCPR untuk melindungi hak hidup, mengupayakan lewat hukum dan menegaskan bahwa hak untuk hidup tidak dapat dirampas secara sewenang-wenang. Selanjutnya Pasal 6 Ayat (2) ICCPR, yaitu:

"In countries which have not abolished the death penalty, sentence of death may be imposed only for the most serious crimes in accordance with the law in force at the time of the commission of the crime and not contrary the provisions of the present Convenant and to the Convention on the Prevention and Punishment of the Crime of Genocide. This penalty can only be carried out pursuant to a final judgement rendered by a competent court."(Dinegara-negara yang belum menghapuskan pidana mati, putusan pidana mati dapat dijatuhkan terhadap beberapa kejahatan yang paling serius sesuai dengan hukum yang berlaku pada saat dilakukannya kejahatan tersebut, dan tidak bertentangan dengan ketentuan Konvenan dan Konvensi tentang Pencegahan dan Hukum Kejahatan Genosida. Pidana ini hanya dapat dilaksanakan atas dasar keputusan akhir yang dijatuhkan oleh suatu pengadilan yang berwenang.)

Pada Pasal 6 Ayat (2) tersebut, frasa "terhadap kejahatan-kejahatan paling berat", frasa ini mengimplementasikan bahwa pidana mati diberlakukan hanya sebagai langkah yang bersifat khusus. Hukuman mati harus tidak melebihi kejahatan berencana (intentional crime) dengan konsekuensi sangat besar dan mematikan.

ICCPR juga memberikan hak bagi terpidana mati untuk mengajukan permohonan pengampunan, hal tersebut dimuat dalam Pasal 6 Ayat (4) ICCPR, yaitu: "Anyone sentenced to death shall have the right to seek pardon or commutation of the sentence. Amnesty, pardon or commutation of the death may be granted in all cases." (setiap orang yang telah dijatuhi pidana mati berhak untuk memohon ampunan atau penggantian pidana. Amnesti, pengampunan dan penggantian pidana mati dapat diberikan dalam semua kasus). ${ }^{31}$

Ketentuan lain pada Pasal 6 ini ialah mengatur tentang hak bagi terpidana mati untuk mendapatkan pengampunan serta mengatur tentang batasan atau larangan

30 Pasal 6 Ayat (1) Undang-Undang Nomor 12 Tahun 2005 tentang Pengesahan International Convenant on Civil and Political Right (Konvenan Internasional tentang Hak-Hak Sipil dan Politik).

31 Pasal 6 Ayat (2) Undang-Undang Nomor 12 Tahun 2005 tentang Pengesahan International Convenant on Civil and Political Right (Konvenan Internasional tentang Hak-Hak Sipil dan Politik). 
menghukum mati atau melakukan ekseksusi pada orang-orang dengan kategori tertentu, larangan eksekusi terhadap anak dibawah 18 tahun dan larangan eksekusi bagi perempuan hamil.32 Hak-hak terpidana mati meliputi Hak sebelum persidangan, Hak saat persidangan, dan Hak setelah persidangan.

Ketentuan hak-hak fair trial lebih spesifik diatur dalam Pasal 9 - 15 Konvenan, antara lain:

1. Hak atas kebebasan dan keamanan pribadi;

2. Hak dan kedudukan yang sama dihadapan pengadilan dan badan peradilan;

3. Hak dianggap tidak bersalah sampai kesalahannya dibutikan menurut hukum;

4. Hak untuk diberitahukan secepatnya dengan rinci dalam bahasa yang dapat dimengertinya, tentang sifat dan alasan tuduhan yang dikenakan;

5. Hak atas waktu yang cukup dan fasilitas yang memadai untuk mempersiapkan pembelaan;

6. Hak untuk diadili tanpa penundaan;

7. Hak untuk memeriksa atau meminta diperiksanya saksi-saksi yang memberatkannya dan meminta dihadirkan dan diperiksanya saksi-saksi yang meringankannya;

8. Hak mendapatkan bantuan cuma-cuma dari penerjemah apabila ia tidak mengerti atau tidak dapat berbicara dalam bahasa yang digunakan di pengadilan;

9. Hak untuk tidak dipaksa memberikan kesaksian yang memberatkan dirinya, atau dipaksa mengaku bersalah; dan lain sebagainya. ${ }^{33}$

Kemudian ICCPR mengatur mengenai penghapusan pidana mati yang tercantum pada bagian akhir Pasal 6 Ayat (6) ICCPR, yaitu: "Nothing in this article shall be invoked to delay or to prevent the abolition of capital punishment by any State Party to the present Convenant."(Tidak ada satu pun dalam pasal ini yang boleh dipakai untuk menunda atau mencegah penghapusan pidana mati oleh Negara yang menjadi Pihak dalam Konvenan ini).

ICCPR pada pasal ini ingin menghendaki agar pidana mati dapat dihapuskan, akan tetapi bagi negara-negara yang belum menghapuskan pidana mati, pada penerapannya ICCPR memberikan batasan-batasan yang sangat ketat agar pidana mati dapat diterapkan.

\section{Ius Constituendum Konsep Batas Waktu Pelaksanaan Pidana Mati dalam}

\section{Perspektif Kepastian Hukum dan Keadilan}

Pidana mati di Indonesia mulai menjadi perdebatan kembali sejak diangkatnya hak untuk hidup bukan hanya sebagai Hak Asasi Manusia yang dilindungi oleh UndangUndang, tetapi juga merupakan hak konstitusional yang pemenuhannya menjadi suatu keharusan. ${ }^{34}$ Penjatuhan sanksi pidana menjadi titik krusial, khususnya sanksi pidana yang terberat yakni pidana mati. Pidana mati merupakan bagian dari realitas dalam sejarah hukum yang ada di dunia. Keberadaannya tidak terlepas dari aspek

32 Zainal Abidin, Menyelisik Keadilan yang Rentan: Hukuman Mati dan Penerapan Fair Trial di Indonesia Jakarta Selatan: Institute for Criminal Justice Reform, 2019), hlm. 38.

34 Eva Achjani Zulfa, "Menakar Kembali Keberadaan Pidana Mati (Suatu Pergeseran Paradigma Pemidanaan di Indonesia)", Lex Jurnalica, Vol. 4, No. 2 (2007), hlm. 93. 
menakutkan atau menjerakan yang bertujuan untuk melindungi masyarakat. Sanksi pidana menjadi salah satu elemen penting dalam hukum pidana, selain norma-norma yang mengatur mengenai perbuatan yang tidak boleh dilakukan atau dilarang. 35

Perdebatan mengenai pidana mati di Indonesia tidak akan pernah lepas dari penghormatan terhadap Hak Asasi Manusia, melalui Putusan Mahkamah Konstitusi Nomor:2-3/PUU-V/2007 tanggal 30 Oktober 2007, maka secara sah dan konstitusional menyatakan bahwa pidana mati tidak bertentangan dengan Pasal 28A dan 28I Ayat (1) UUD NKRI 1945. Indonesia telah meratifikasi ICCPR melalui Undang-Undang Nomor 12 Tahun 2005 tentang Pengesahan International Convenant on Civil and Political Rights (Konvenan Internasional Tentang Hak-hak Sipil dan Politik), adapun alasan-alasan pidana mati masih diberlakukan, antara lain:

1. Pidana mati masih sangat diperlukan terhadap pelaku tindak kejahatan berat (Narkotika, Terorisme, Pembunuhan Berencana, dan lain sebagainya), sehingga penjatuhan pidana mati memenuhi aspek keadilan dan seimbang dengan tindak pidana yang dilakukan. Menurut Andi Hamzah, pidana mati merupakan alat penting untuk penerapan yang baik dari hukum pidana. ${ }^{36}$

2. Pidana mati dapat digunakan sebagai sarana yang mencegah seseorang untuk melakukan tindak kejahatan, karena pidana mati merupakan pidana yang sifatnya menakutkan dan menjerakan. Menurut Anselm Von Feuerbach melalui teorinya Psycologishe Zwang (paksaan psikologis), pidana mati dapat memberikan aspek manfaat dan akan menimbulkan rasa takut bagi orang lain untuk melakukan tindak kejahatan yang diancam dengan hukuman mati. ${ }^{37}$

3. Pidana mati sudah ada sejak Pemerintahan Majapahit, jadi secara historis penjatuhan pidana mati bukan merupakan suatu hal yang baru bagi masyarakat Indonesia.

4. Aspek kepastian hukum masih tercantum di dalam ketentuan KUHP dan di luar KUHP, termasuk tata cara pelaksanaan pidana mati. Terdapat argumentasi mengenai pemberlakuan pidana mati, dikemukakan oleh Barda Nawawi Arief, yang menyatakan bahwa dipertahankannya pidana mati lebih menitikberatkan atau berorientasi pada perlindungan kepentingan masyarakat, namun pada penerapannya diharapkan bersifat selektif, hati-hati, serta berorientasi juga pada kepentingan individu (pelaku tindak pidana). ${ }^{38}$

Berdasarkan Putusan Mahkamah Konstitusi tersebut sudah sewajarnya untuk dijadikan komitmen dari penegak hukum untuk melaksanakannya secara konsisten, hati-hati, serta cermat dalam hal menjatuhkan pidana mati. Namun tidak hanya sebatas itu saja melainkan juga mengenai pelaksanaan eksekusi pidana mati yang dilaksanakan dengan mempertimbangkan aspek kepastian hukum dan keadilan.

35 Djernih Sitanggang, Kepastian Hukum, hlm. 215.

36 Fransiska Novita Eleanora, Eksistensi Pidana Mati dalam Perspektif Hukum Pidana (Jakarta: Universitas Mpu Tantular, 2012), hlm. 12.

37 M. Ali Zaidan, "Dari Rehabilitasi Menuju Rekonsiliasi (Kasus Kelompok Rentan Berhadapan Dengan Hukum)", Jurnal Hukum Doctrinal, Vol. 1, No. 2 (2016), hlm. 7.

38 Barda Nawawi Arief, Bunga Rampai Kebijakan Hukum Pidana (Bandung: Citra Aditya Bakti, 2005), hlm. 238. 
Masalah penegakan hukum terletak pada faktor-faktor yang mungkin mempengaruhinya, ada pun faktor-faktor tersebut adalah:

1. Faktor hukumnya sendiri, dibatasi pada undang-undang;

2. Faktor penengak hukum, yaitu pihak-pihak yang membentuk maupun menerapkan hukum;

3. Faktor sarana atau fasilitas yang mendukung penegakan hukum;

4. Faktor masyarakat, yaitu lingkungan dimana hukum tersebut berlaku atau diterapkan;

5. Faktor kebudayaan, yaitu sebagai hasil karya, cipta, dan rasa yang didasarkan pada karsa manusia di dalam pergaulan hidup. ${ }^{39}$

Keberhasilan penegakan hukum terletak pada faktor-faktor yang mempengaruhinya, salah satunya faktor penegak hukum. ${ }^{40}$ Dengan tidak diaturnya secara tegas mengenai batas waktu pelaksanaan eksekusi terpidana mati, baik dari fase pemenuhan hak hingga fase penolakan grasi oleh Presiden.

Dalam usaha memberikan kepastian hukum, adanya penerapan atau penegakan hukum yang konsisten dalam hal terjadi pelanggaran hukum. ${ }^{41}$ Menurut Jan M. Otto bahwa kepastian hukum dalam situasi tertentu mensyaratkan:

1. Tersedia aturan-aturan hukum yang jelas atau jernih, konsisten dan mudah diperoleh (accessible), yang diterbitkan oleh kekuasaan negara;

2. Bahwa instansi-instansi penguasa (pemerintah) menerapkan aturanaturan hukum secara konsisten dan juga tunduk dan taat kepadanya;

3. Bahwa mayoritas warga pada prinsipnya menyetujui muatan isi dan karena itu menyesuaikan prilaku mereka terhadap aturan tersebut;

4. Bahwa hakim-hakim (peradilan) yang mandiri dan tidak berpihak menerapkan aturan-aturan hukum tersebut secara konsisten sewaktu mereka menyelesaikan sengketa hukum; dan

5. Bahwa keputusan peradilan secara konrit dilaksanakan. ${ }^{42}$

Kelima syarat kepastian hukum tersebut menunjukan kepastian hukum tidak hanya menyangkut persoalan yang berkaitan dengan substansi hukum saja, melainkan termasuk pada pelaksanaan hukum oleh instansi-instansi negara serta lembaga peradilan. Selama ini aspek kepastian hukum mengenai penjatuhan pidana mati telah tercantum di dalam KUHP dan juga di luar KUHP, namun pengaturan mengenai pelaksanaan eksekusi pidana mati tanpa tersedia aturan-aturan hukum yang pasti dan konsisten dalam mengatur batas waktu pelaksanaannya atau batas terakhir eksekusi mati dijalankan dan atau dapat dikatakan sebagai masa tunggu. Upaya pemerintah dalam menangani pemasalahan mengenai pengaturan hukuman mati tengah diupayakan melalui RKUHP, dengan menjadikan pidana mati bukan sebagai pidana pokok melainkan sebagai pidana yang bersifat khusus untuk tindak pidana tertentu yang ditentukan dalam Undang-Undang. ${ }^{43}$

39 Djernih Sitanggang, Kepastian Hukum, hlm. 113.

40 Djernih Sitanggang, Kepastian Hukum, hlm. 113.

41 Usman dan Andi Najemi, "Mediasi Penal di Indonesia”, hlm. 80.

42 Shidarta, Moralitas Profesi Hukum: Suatu Tawaran Kerangka Berfikir (Bandung: PT Refika Aditama, Cet. Pertama, 2006), hlm. 123.

43 Pasal 64 huruf C RKUHP 2019. 
Penjatuhan pidana mati dapat dijatuhkan dengan masa percobaan selama 10 (sepuluh) tahun, dalam Pasal 100 Ayat (1) RKUHP menentukan: "Hakim dapat menjatuhkan pidana mati dengan masa percobaan selama 10 (sepuluh) tahun jika:

1. Terdakwa menunjukan rasa menyesal dan ada harapan untuk diperbaiki;

2. Peran terdakwa dalam tindak pidana tidak terlalu penting; atau

3. Ada alasan yang meringankan.

Pasal 100 Ayat (4) RKUHP memberikan kemungkinan bahwa pidana mati dapat diubah menjadi pidana penjara seumur hidup dengan Keputusan Presiden dan pertimbangan Mahkamah Agung. ${ }^{44}$ Dalam ketentuan Pasal 101 menegaskan apabila terpidana mati yang mengajukan permohonan grasi telah ditolak dan pidana mati tidak dilaksanakan selama 10 (sepuluh) tahun sejak grasi ditolak bukan karena terpidana melarikan diri, pidana mati dapat diubah menjadi penjara seumur hidup dengan Keputusan Presiden setelah mendapat pertimbangan dari Mahkamah Agung. 45

Tim perumus draft RKUHP menyebut ini sebagai "The Indonesian Way" terhadap ketentuan pidana mati di masa mendatang. Namun penjatuhan pidana mati percobaan hanya dapat diberikan apabila terdapat pernyataan oleh Hakim secara tegas dalam putusan, sesuai kriteria tersebut.

Berdasarkan draft RKUHP apabila hakim tidak menjatuhkan pidana mati percobaan maka penulis melihat pembaharuan terhadap batas waktu pelaksanaan pidana mati memiliki 2 (dua) fase dengan membagi waktu 10 (sepuluh) tahun yang ada dalam RKUHP, fase yang pertama yakni fase pemenuhan hak-hak dari terpidana mati berupa upaya hukum luar biasa peninjauan kembali dan grasi, kemudian fase pasca penolakan grasi oleh Presiden.

Pada tahap pertama upaya hukum luar biasa peninjauan kembali dari awal proses pengajuan sampai adanya putusan peninjauan kembali dari Mahkamah Agung, jangka waktu yang diperlukan yaitu selama 5 (lima) tahun ketentuan ini akan dicantumkan di dalam perubahan KUHAP.

Tahap kedua setelah adanya putusan peninjauan kembali, yaitu hak terpidana mati untuk mengajukan grasi kepada Presiden. Pengajuan grasi dari awal proses sampai adanya Keputusan Presiden yang mengabulkan atau menolak permohonan grasi, jangka waktu yang diperlukan yaitu selama 4 (empat) tahun. Tahapan kedua dimulai sejak berakhirnya tahapan pertama yaitu upaya hukum luar biasa peninjauan kembali. Jangka waktu 4 (empat) tahun ini akan dicantumkan dalam UU Grasi, sebagai antisipasi kekosongan hukum dengan adanya Putusan Mahkamah Konstitusi Nomor 107/PUU-XIII/2015 yang membatalkan ketentuan Pasal 7 Ayat (2) UU Grasi perihal permohonan grasi diajukan paling lambat 1 (satu) tahun sejak putusan memperoleh kekuatan hukum tetap.46 Apabila terpidana mati tidak mengajukan upaya hukum luar biasa peninjauan kembali dalam kurun waktu 5 (lima) tahun, maka permohonan grasi tidak dapat diajukan karena terpidana mati masih dalam tahap pembinaan.

Pembinaan terhadap terpidana mati tetap diperlukan untuk mengisi waktu luang selama menunggu eksekusi. Program pembinaan bagi terpidana mati

44 Pasal 100 Ayat (4) RKUHP 2019.

45 Pasal 101 RKUHP 2019.

46 Lihat Putusan Mahkamah Konstitusi Nomor 107/PUU-XIII/2015. 
bertujuan untuk memberikan kebaikan bagi terpidana mati agar menyadari kesalahan, memperbaiki diri, tidak melakukan tindakan yang melanggar hukum selama di Lapas. Program pembinaan dan kegiatan yang diikuti terpidana mati akan dimasukkan ke dalam Buku Perwalian Warga Binaan Pemasyarakatan. Argumentasi ini didukung oleh pendapat Edi Warsono, Kepala Seksi Bimbingan Kemasyarakatan Lapas Klas I Batu Nusakambangan yang menyatakan umumnya narapidana dan terpidana mati menunjukan indikasi berperilaku baik dalam jangka waktu 3 (tiga) sampai 5 (lima) tahun sejak berada di Lapas. ${ }^{47}$ Yang artinya dalam kurun waktu tersebut terpidana mati yang tengah mengajukan upaya hukum telah dapat dilakukan penilaian, sehingga dapat diputuskan pemberian atau penolakan grasi oleh Presiden.

Program pembinaan mempunyai arti penting sebagai bentuk pelayanan kesehatan kepada terpidana mati dalam mengatasi tekanan atau gangguan psikis. Pembinaan kepribadian melalui bimbingan kerohanian, bimbingan konseling, serta pembinaan kemandirian melalui latihan kerja yang diharapkan efektif menyelesaikan permasalahan ini. Selama menunggu kepastian eksekusi maka program pembinaan menjadi suatu keharusan yang harus dilaksanakan secara wajib bagi terpidana mati. Pembinaan bertujuan untuk memberikan waktu kepada Petugas Lapas melakukan penilaian terhadap perilaku terpidana mati selama di Lapas serta untuk mempersiapkan terpidana mati untuk menghadapi eksekusi mati, selain itu nantinya program pembinaan akan menjadi bahan pertimbangan bagi Presiden untuk mempertimbangkan permohonan grasi yang diajukan oleh terpidana mati. Perubahan ini akan dicantumkan di dalam UU Pemasyarakatan, untuk memberikan keadilan dengan memberikan persamaan hak-hak yang diterima oleh sesama penghuni Lapas lainnya.

Jangka waktu fase pemenuhan hak terpidana mati mulai dari mengajukan upaya hukum luar biasa peninjauan kembali dan grasi secara keseluruhan membutuhkan waktu selama 10 (sepuluh) tahun. Fase pemenuhan hak terpidana mati hanya dilakukan apabila terpidana mati menggunakan haknya, bagi terpidana mati yang sejak awal putusan telah berkekuatan hukum tetap telah menyatakan tidak akan mengajukan upaya hukum luar biasa peninjauan kembali atau grasi, maka pihak Kejaksaan dapat segera mengeksekusi tanpa harus menunggu jangka waktu tersebut selesai.

Selanjutnya fase pasca penolakan grasi, maka tugas dari Kejaksaan untuk segera mengeksekusi terpidana mati yang bersangkutan. Mulai dari kelengkapan administrasi dan sebagainya, dan jangka waktu yang diberikan kepada Kejaksaan yaitu 1 (satu) tahun terhitung sejak penetapan Keputusan Presiden mengenai penolakan grasi. Penggunaan jangka waktu 1 (satu) tahun bertujuan agar Kejaksaan dapat membuat agenda dan mempersiapkan eksekusi terpidana mati untuk anggaran tahun berikutnya. Ketentuan perubahan ini akan dicantumkan dalam UU No.2/Penpres/1964. Dasar pertimbangan 1 (satu) tahun yakni pada perbandingan negara Malaysia dan Singapura, yang hanya memberikan waktu eksekusi paling lama 1 (satu) tahun sejak penolakan grasi. ${ }^{48}$

47 Djernih Sitanggang, Kepastian Hukum, hlm. 303.

48 Djernih Sitanggang, Kepastian Hukum, hlm. 304. 
Pembaharuan batas waktu pelaksanaan eksekusi pidana mati dilaksanakan secara komprehensif, tidak hanya terfokus pada pengaturan masa tunggu, akan tetapi menekankan pula agar adanya harmonisasi dan singkronisasi dengan ketentuan-ketentuan yang mengatur mengenai peninjauan kembali dan grasi, serta memberikan jangka waktu yang pasti pasca penolakan grasi dilaksanakan oleh penegak hukum dengan konsisten.

"Pembangunan hukum pidana melalui pembaharuan perundang-undangan pada hakikatnya merupakan bagian dari suatu kebijakan yang diperuntukkan sebagai pembaharuan substansi hukum (legal substance) dalam rangka mengefektifkan penegakan hukum. Pembaharuan hukum pidana tidak dapat dilepaskan dari ide atau kebijakan pembangunan sistem hukum nasional yang berlandaskan Pancasila, hal ini mengandung pengertian bahwa pembaharuan hukum pidana nasional seyogyanya juga harus dilatarbelakangi oleh sumbersumber yang berorientasi pada ide dasar (basic idea) Pancasila yang di dalamnya mengandung konsep Ketuhanan, Kemanusiaan, Kebangsaan, Demokrasi dan Keadilan Sosial."49

Besar harapan konsep ini nantinya akan mempermudah Kejaksaan dalam memberikan landasan kepastian hukum. "Kepastian hukum berupa keamanan individu dari kesewenangan pemerintah, dan apa saja yang boleh dibebankan atau dilakukan negara kepada individu." 50 Serta memberikan keadilan terhadap terpidana mati selama proses pemenuhan hak-hak sebelum dilaksanakannya eksekusi mati. Konsep "Batas Waktu Pelaksanaan Pidana Mati dalam Perspektif Kepastian Hukum dan Keadilan di Indonesia”, bertujuan agar pelaksanaan eksekusi pidana mati agar dapat dipertanggungjawabkan dan tidak bertentangan secara Hak Asasi Manusia.

\section{SIMPULAN}

Artikel ini menyimpulkan pertama, dalam hukum positif Indonesia tidak ditemui ketentuan yuridis yang secara tegas mengatur batas waktu pelaksanaan eksekusi pidana mati sehingga sering kali terkendala dalam menentukan batas akhir dilaksanakannya eksekusi terhadap terpidana mati, selain itu kerap ditemui pelanggaran atas hak asasi manusia terhadap terpidana mati selama menanti eksekusi di Lembaga Pemasyarakatan. Akibat dari tidak jelasnya pengaturan mengenai batas akhir pelaksanaan eksekusi maka pelaksanaan eksekusi pidana mati di Indonesia belum memenuhi aspek kepastian hukum dan keadilan berdasarkan hak-hak yang terdapat dalam Undang-Undang Dasar Negara Republik Indonesia Tahun 1945, DUHAM, serta ICCPR. Kedua, pengaturan pidana mati kedepannya akan dilaksanakan dengan diterapkannya pidana mati percobaan oleh Hakim, namun apabila hakim tidak menerapkan pidana percobaan terhadap terpidana maka dapat dilaksanakan dalam kurun waktu 10 tahun, meliputi fase pemenuhan hak-hak terpidana mati baik selama di Lembaga Pemasyarakatan dengan mengajukan upaya hukum hingga fase pasca penolakan grasi oleh Presiden, sehingga dengan demikian pelaksanaan eksekusi

49 Djernih Sitanggang, Kepastian Hukum, hlm. 292.

50 Peter Mahmud Marzuki, Pengantar Ilmu Hukum (Jakarta: Kencana, Cet. Ke-10, 2017), hlm. 137. 
pidana mati dapat memenuhi aspek tujuan hukum yakni, kepastian hukum, keadilan, dan juga kemanfaatan dari penerapan pidana mati di Indonesia.

\section{DAFTAR PUSTAKA}

\section{Dokumen Hukum:}

Kitab Undang-Undang Hukum Pidana.

Putusan Mahkamah Konstitusi Nomor 107/PUU-XIII/2015.

Republik Indonesia. Undang-Undang Tentang Hukum Acara Pidana.UU Nomor 8 Tahun 1981.

Republik Indonesia. Undang-Undang Tentang Perubahan atas Undang-Undang Nomor 31 Tahun 1999 Tentang Pemberantasan Tindak Pidana Korupsi. UU Nomor 20 Tahun 2001. LNRI Tahun 2001 Nomor 134, TLNRI Nomor 4150.

Republik Indonesia. Undang-Undang Tentang Komisi Pemberantasan Tindak Korupsi. UU Nomor 30 Tahun 2002. LNRI Tahun 2002 Nomor 137. TLNRI Nomor 4250.

Republik Indonesia. Undang-Undang Tentang Pengadilan Tindak Pidana Korupsi. UU Nomor 46 Tahun 2009. LNRI Tahun 2009 Nomor 155. TLNRI 5074.

Republik Indonesia. Undang-Undang Tentang Grasi. UU Nomor 22 Tahun 2002. LNRI Tahun 2002 Nomor 108. TLNRI Nomor 4234.

Republik Indonesia. Undang-Undang Tentang Grasi. UU Nomor 5 tahun 2010 Tentang Perubahan Atas Undang-Undang Nomor 22 Tahun 2002 Tentang Grasi. LNRI Tahun 2010 Nomor 100. TLNRI Nomor 5150.

Republik Indonesia. Undang-Undang Tentang Pemasyarakatan. UU Nomor 12 Tahun 1995. LNRI Tahun 1995 Nomor 77. TLNRI Nomor 3614.

Republik Indonesia. Undang-Undang Tentang Hak Asasi Manusia. UU Nomor 39 Tahun 1999. LNRI Tahun 2000 Nomor 208. TLNRI Nomor 3886.

Republik Indonesia. Undang-Undang Tentang Pemberantasan Tindak Pidana Terorisme. UU Nomor 5 Tahun 2018 Tentang Perubahan Atas UndangUndang Nomor 15 Tahun 2003 Tentang Penetapan Peraturan Pemerintah Pengganti Undang-Undang Nomor 1 Tahun 2002 Tentang Pemberantasan Tindak Pidana Terorisme. LNRI Tahun 2018 Nomor 92. TLNRI Nomor 6216.

Republik Indonesia. Undang-Undang Tentang Narkotika. UU Nomor 35 Tahun 2009 Tentang Perubahan Kedua Atas Undang-Undang Nomor 22 Tahun 1997 Tentang Narkotika. LNRI Tahun 2009 Nomor 143. TLNRI Nomor 5062. 


\section{Buku:}

Abidin, Zainal. Menyelisik Keadilan yang Rentan: Hukuman Mati dan Penerapan Fair Trial di Indonesia. Jakarta Selatan: Institute for Criminal Justice Reform, 2019.

Arief, Barda Nawawi. Bunga Rampai Kebijakan Hukum Pidana. Bandung: Citra Aditya Bakti, 2005.

Budiman, Adhigama Andre. Laporan Situasi Kebijakan Hukuman Mati di Indonesia 2020: Mencabut Nyawa di Masa Pandemi. Jakarta Selatan: Institute for Justice and Criminal Reform, 2020.

Budiman, Adhigama Andre \& Maidina Rahmawati. Fenomena Deret Tunggu Terpidana Mati di Indonesia, Jakarta Selatan: Institute for Criminal Justice Reform, 2020.

Marzuki, Peter Mahmud. Pengantar Ilmu Hukum. Jakarta: Kencana, Cet. Ke-10, 2017.

Napitupulu, Erasmus A.T. Laporan Situasi Kebijakan Hukuman Mati di Indonesia: “Mempermainkan Takdir", 2019.

Ravena, Dey \& Kristian, Kebijakan Kriminal (Criminal Policy). Jakarta: Kencana, Cet. Pertama, Jakarta, 2017.

Shidarta. Moralitas Profesi Hukum: Suatu Tawaran Kerangka Berfikir. Bandung: PT Refika Aditama, Cet. Pertama, 2006.

Sitanggang, Djernih. Kepastian Hukum Masa Tunggu Eksekusi Pidana Mati Dalam Mewujudkan Rasa Keadilan Menuju Pembaharuan Hukum Pidana. Bandung: Pustaka Reka Cipta, Cet. Pertama, 2018.

Waluyo,Bambang. Penegakan Hukum di Indonesia. Jakarta: Sinar Grafika, 2016.

\section{Jurnal:}

Asmaran, Marselinus Yohanes Rian. "Pelaksanaan Aturan Limitasi Waktu Eksekusi Terpidana Mati”, Jurnal Universitas Atma Jaya Yogyakarta, (2017).

Aulia, M. Zulfa. "Hukum Pembangunan dari Mochtar Kusumaatmadja: Mengarahkan Pembangunan atau Mengabdi pada Pembangunan", Undang Jurnal Hukum, Vol.1 No.2 (2018).

Efendi, Roni."Konstitusionalitas Masa Tunggu Eksekusi Bagi Terpidana Mati dalam Sistem Pemidanaan", Jurnal Konstitusi, Vol. 16, No. 2 (2019).

Eleanora, Fransiska Novita. "Eksistensi Pidana Mati dalam Perspektif Hukum Pidana", Universitas Mpu Tantular Jakarta, (2012).

Nababan, Monika Dwi Putri \& Kabib Nawawi, "Pelaksanaan Hak Tahanan (Tantangan dan Permasalahan)", PAMPAS: Journal of Criminal Law, Vol. 1, No. 1 (2020).

Oktavia, Leny. "Pelaksanaan Pembinaan Narapidana yang Dijatuhi Pidana Mati (Studi Kasus Lembaga Permasyarakatan Kelas 1 A Raja Basssa Bandar Lampung)" Poenale: Jurnal Bagian Hukum Pidana, (2019). 
Usman \& Andi Najemi, "Mediasi Penal di Indonesia: Keadilan, Kemanfaatan, dan Kepastian Hukumnya", Undang: Jurnal Hukum, Vol.1, No.1, 2018.

Zaidan, M. Ali. "Dari Rehabilitasi Menuju Rekonsiliasi (Kasus Kelompok Rentan Berhadapan Dengan Hukum)", Jurnal Hukum Doctrinal, Vol. 1, No. 2 (2016).

Zulfa, Eva Achjani. "Menakar Kembali Keberadaan Pidana Mati (Suatu Pergeseran Paradigma Pemidanaan di Indonesia)”, Lex Jurnalica, Vol. 4, No. 2 (2007).

\section{Internet:}

Dhani Irawan, "Cerita Freddy Budiman Atur Bisnis Narkoba dan Nyabu Bareng Model Dilapas", detikNews, Berita, 29/7/2016, diakses pada tanggal 31 Oktober 2019.

Hilda Meilisa, "Eksekusi Mati Sugik, Pembunuh Satu Keluarga Mungkin Dibatalkan, Ini Sebabnya”, detikNews, Berita Jawa Timur, 31/12/2019, diakses pada tanggal 17 Februari 2020.

Ita Lismawati F. Malau, "Rentetan Kasus Hukum Freddy Budiman si Gembong Narkoba", Viva News,Berita, 30/9/2010, diakses pada tanggal 02 Februari 2020. 